\title{
Glutensiz Diyetin Sağlık Üzerine Etkileri
}

\author{
The Effects of Gluten-free Diet on Health
}

\author{
Hande Gül Ulusoy ${ }^{1}$, Neslişah Rakıcıoğlu ${ }^{2}$
}

Geliş tarihi/Received: 25.04.2019 • Kabul tarihi/Accepted: 14.08.2019

\section{ÖZET}

Glutensiz diyetler, başlıca çölyak hastalığı olmak üzere irritabl bağırsak sendromu, otizm, romatoid artrit, şizofreni, atopi, fibromiyalji, endometriozis ve kronik pelvik ağrı, atletik performans ve vücut ağırlık kaybı diyetlerinde kullanılmaktadır. Glutensiz diyetin, uygulayanlarda protein, diyet posası, vitamin ve mineraller gibi bazı besin ögesi eksikliklerine neden olabileceği bildirilmiştir. Glutensiz besinlerin enerji ve yağ içeriklerinin yüksek olmasından dolayı glutensiz diyete uyum sonrası, vücut ağırlığı kaybı yerine vücut ağırlığı kazanımı meydana gelebilmektedir. Ayrıca glutensiz besinlerin yağ içeriği yüksek olduğundan kardiyovasküler risk faktörleri açısından da dikkatli olunmalıdır. Glutensiz diyetlerde sık görülen besin ögesi yetersizliklerini önlemek için gluten içermeyen ve besin ögeleri açısından zengin alternatif tahılların tüketilmesinin yanı sıra posa ve birçok besin ögesinden zengin sebze, meyve ve kurubaklagil tüketimine de önem gösterilmelidir.

Anahtar kelimeler: Diyet, glutensiz, sağlık

\begin{abstract}
Gluten-free diets, are used mainly in celiac disease, including irritable bowel syndrome, autism, rheumatoid arthritis, schizophrenia, atopy, fibromyalgia, endometriosis and chronic pelvic pain, athletic performance and weight loss diets. It has been reported that people on gluten-free diet may have some nutrient deficiencies such as protein, dietary fiber, vitamins and minerals. Due to the high energy and fat content of gluten-free foods, body weight gain may occur instead of loss after compliance with gluten-free diet. In addition, due to the high fat content of gluten-free foods, caution should be taken for cardiovascular risk factors. In order to prevent nutrient deficiencies that are common in gluten-free diets, care should be taken to consume naturally gluten-free and nutrient-rich alternative cereals, fiber and many nutrients-rich vegetables, fruits and legumes.
\end{abstract}

Keywords: Diet, gluten-free, health

1. İletişim/Correspondence: Lokman Hekim Üniversitesi, Sağllk Bilimleri Fakültesi, Beslenme ve Diyet Bölümü, Ankara, Türkiye • E-posta: handegululusoy@gmail.com (1) https://orcid.org/0000-0003-2824-0543
2. Hacettepe Üniversitesi, Sağlık Bilimleri Fakültesi, Beslenme ve Diyetetik Bölümü, Ankara, Türkiye (1) https://orcid.org/0000-0001-8763-7407 


\section{GİRIŞ}

Gluten, bazı çiçekli bitki türleri tarafından tohumun çimlenmesi ve büyümesi için enerji kaynağı olarak kullanılan depo proteindir. Buğday, arpa ve çavdar gibi bazı tahılların endosperminde bulunmaktadır. Gluten yapısında $\alpha$, $\beta$ ve $\gamma$ peptidlerini üretebilen iki grup protein olan, glutelin ve prolamin (buğdayda gliadin) karışımıdır (1). Gluten kompleksinin oluşması için tahılda glutelin ile prolaminin eşit miktarda bulunması ve su ile birleşmesi gerekmektedir (2).

Çölyak hastalığı, II. Dünya Savaşı sırasında buğday tüketimi ile ilişkili bir hastalık olarak tanımlanmıştır. Günümüzde klinik, immünolojik ve genellikle histolojik tanı yöntemleri ile tanı konulmaktadır. Hastalığın tedavisi ise ömür boyu glutensiz diyete uymaktır (3). Karakteristik klinik yanıt, esas olarak gliadin (buğday), sekalin (çavdar), hordein (arpa) ve tritikale (buğday ve çavdarın hibriti) dahil olmak üzere bir grup tahılda bulunan proteine (gluten) maruz kalma ile tetiklenmektedir (4).

Glutensiz diyetler, temel olarakgluten eliminasyonuna dayanmaktadır. Glutensiz diyetlerin temel ilkesi; buğday, arpa, çavdar, yulafin ve bu tahıllardan üretilmiş (nişasta, un, ekmek, makarna, kek vb.) ürünlerin eliminasyonunu sağlamaktır. Çölyak hastalarında günlük yulaf tüketiminin çocuklar için 20-25 g, yetişkinler için 50-75 g geçmemesi ve bu hastaların izlenmesi önerilmektedir (5). Glutensiz diyetlerde yulafın, kontamine olmaması koşuluyla günde 50 grama kadar tolere edilebildiği belirtilmiştir (6). Ancak, glutensiz diyetlerde yulaf tüketimi ile ilgili öneriler ticari yulafın diğer tahıllarla kontaminasyon riskinin yüksek olması nedeniyle hala net değildir (6).

Otoimmün hastalık, alerji veya besin hassasiyeti olmayan durumlarda gluten içeren besinleri tüketmemenin sağlık üzerine etkileri henüz tam olarak açıklık kazanmamıştır (7). Bu belirsizliğe rağmen, glutenle ilişkili hastalığı olmayan ve glutensiz diyetin sağlıklı olduğunu düşünüp uygulayan bireylerin prevalansının Batı ülkelerinde \%6.2-
13 arasında değiştiği belirtilmektedir (8). Amerika Birleşik Devletleri'nde her beş yetişkinden birinin sağlık nedenleri ile glutensiz diyet uyguladıkları saptanmıştır (9). Glutensiz diyetlerin sağlıklı bireyler tarafindan uygulanmasinda artan bir talep olmasina rağmen, yararlı sonuçları destekleyen kanıtlar oldukça sinırlıdır (10). Glutensiz diyetin sağlık üzerine etkilerinin değerlendirildiği bir derlemede, glutensiz diyetin vücut ağırlığı kaybı amacıyla uygulanması için yeterli kanıt olmadığı belirtilmiştir (20). Aksine araştırmalar glutensiz diyet modeline uyumun karbonhidrat, posa, demir, çinko, folat ve niasin açısından yetersiz beslenme ile sonuçlanabileceğini göstermektedir (11-13). $\mathrm{Bu}$ derleme yazıda glutensiz diyetlerin sağlık üzerine olası etkilerinin değerlendirilmesi amaçlanmıştır.

\section{Glutensiz Diyetlerin Besin Ögeleri İçeriği}

Glutensiz diyet uygulayanlarm \%20-38'inin enerji, protein, diyet posası, vitamin ve mineraller gibi bazı besinögesi eksikliklerine sahip olduğu belirtilmektedir (14). Bu kapsamda eksiklikleri önlemek için glutensiz diyetler makro ve mikro besin ögeleri gereksinimlerini karşılamalı, dengeli ve uygulanabilir olmadır (15).

Gluteni uzaklaştırmak için besinlerin işlenmesi, besinin makro ve mikro besin ögesi bileşimini dolayısıyla besin kalitesini değiştirmektedir. Glutensiz ürünler demir, folat, B vitaminleri ve posa bakımından daha fakirdir. Bunun yanı sıra gluten içeren besinlerin eşdeğerlerine göre glisemik indeksleri daha yüksektir ve daha yüksek karbonhidrat, yağ içeriğine sahiptirler (16). Bu nedenle çölyak hastalarında yüksek miktarda toplam yağ ve doymuş yağ tüketimi görülürken, düşük miktarda posa alımı görülmektedir $(14,16)$. Önerilen posa alımına ulaşmak için glutensiz diyetlerde yaygın olarak tüketilen patates ve pirinç gibi posa içeriği düşük glutensiz tahıllar yerine karabuğday, amarant, kinoa gibi posa içeriği yüksek (7-10 g/100 g) tahılların veya kurubaklagillerin tüketimi önerilebilir. Besin 
ögesi yetersizliklerinin önlenmesi için gerekli mikro besin ögelerinin sağlanması günde en az 4-5 porsiyon sebze ve meyve tüketimi ile desteklenmelidir (17).

Çölyak hastalığı tanı anında görülen besin ögesi eksiklikleri, mukoza hasarı nedeniyle besin ögesi malabrospsiyonuna bağlı olsa da villöz atrofinin belirgin olduğu hastalarda demir, bakır, folat, B12 vitamini ve çinko gibi besin ögesi eksikliklerinin arttığı belirtilmektedir (16). Çölyak hastalığı olan bireyler, yüksek miktarlarda enerji, yağ ve şeker içeren besinleri tüketerek, glutensiz diyetin kısıtlamalarını telafi etme eğilimindedir (14). Glutensiz diyet uygulayan çölyak hastası yetişkinlerin, vücut kompozisyonu ve besin ögeleri alımının değerlendirildiği bir çalışmada; glutensiz diyet uygulayanların diyetlerinin yeterli ve dengeli olmadığı ve yağdan gelen enerjinin daha yüksek, karbonhidratlardan gelen enerjinin daha düşük oranda olduğu belirtilmiştir (18).

\section{Gluten İle İlişkili Hastalıklarda Glutensiz Diyet}

Gluten ile ilişkili hastalıklar başta çölyak hastalığı olmak üzere çölyak olmayan gluten duyarlılığı, buğday alerjisi ve gluten ataksisidir (19). Karakteristik klinik yanıtı glutene maruz kalma ile tetiklenen çölyak hastalığının tedavisi ömür boyu glutensiz diyettir $(3,4)$. Hastaların periyodik olarak izlenmesi ve diyete uyumu değerlendirmek için antitransglutaminaz antikorları ile rutin olarak test edilmesi önerilmektedir (20). Çölyak hastaları, bu hastalığının besinle ilişkili otoimmün bir hastalık olduğu ve besin alerjisi olmadığı konusunda dikkatli bir şekilde bilgilendirilmelidir (3). Gluten tüketilmesinden kaynaklanan tek hastalık çölyak hastalığı değildir (21). Çölyak hastası olmayan ancak gluten duyarlılığı olanların da glutensiz diyet uygulamaları gerekirken, buğday alerjisi olanların ise buğdaydan kaçınmaları gerekmektedir (19). Genetik olarak duyarlı bireylerde gluten alımının neden olduğu immün aracılı bir hastalık olan gluten ataksisi, glutensiz diyet ile tedavi edildiğinde ataksi iyileşebilmekte ve ilerlemesi engellenebilmektedir (22).

\section{Diğer Hastalıklarda Glutensiz Diyet}

\section{İrritabl bağırsak sendromu}

İrritabl barsak sendromu (İBS), prevalansı \%10-20 olan ve karın ağrısı veya bağırsak alışkanlığında bir değişiklik ile ilişkili fonksiyonel bir bağırsak bozukluğudur. Yaşam kalitesini ve sosyal hayatı güçlü bir şekilde etkileyen İBS’nin etiyolojisi tam olarak anlaşılamamıştır. İBS tedavisi için düşük fermente edilebilir oligosakkaritler, disakkaritler, monosakkaritler ve polioller (FODMAP) diyeti giderek ilgi görmektedir $(23,24)$. Düşük FODMAP diyeti gibi glutensiz diyetin de irritabl bağırsak sendromlu hastalar için olası bir diyet tedavisi olduğu düşünülmektedir. FODMAP diyeti gibi beslenme ile ilişkili yaşam kalitesini fazla düşürmeyen glutensiz diyetin, İBS hastaları için daha pratik bir seçenek olabileceği belirtilmiştir (8). Randomize kontrollü bir çalışmada, glutenin özellikle insan lökosit antijeni (Human leukocyte antigen, HLA) DQ2/8pozitif diyare baskın İBS'li hastalarda, bağırsak bariyer fonksiyonlarını değiştirdiği ve bu nedenle glutensiz diyetin bu bozukluğu tersine çevirebilen bir mekanizması olabileceği öne sürülmüştür (25).

Gluten hassasiyeti ve İBS semptomları olan hastaların, çocukluk çağında tahıl kökenli olmayan besin alerjilerinin yanı sira atopik hastalıkların prevalansının da yüksek olduğu bildirilmiştir. Pediatrik popülasyonda yapılan bir çalışmada, İBS benzeri gastrointestinal semptomları olan ve negatif doku transglutaminaz antikorları veya HLA-DQ2/8 ile mukozal lezyonları olan hastaların \%30'unda glutensiz diyet ile hem atopik hem de gastrointestinal semptomlarda iyileşme olduğu gösterilmiştir (26).

\section{Otizm}

Otizm spektrum bozukluklarının etiyolojisinden genetik ve çevresel faktörler sorumludur. Glutensiz diyetin otizm spektrum bozukluğu olan çocuklarda, gastrointestinal semptomlar ve davranış indeksleri üzerindeki etkisini araştırmak amacıyla yapılan 
randomize klinik bir çalışmada, otizm spektrum bozukluğu tanısı konmuş 80 çocuğa 6 hafta boyunca glutensiz diyet $(n=40)$ ve normal diyet $(n=40)$ verilmiştir (27). Gastrointestinal semptom prevalansinin glutensiz diyet uygulamasindan sonra anlamlı olarak azaldığı (\%40.6’dan \%17.1'e), normal diyet grubunda ise anlamlı bulunmasa da arttığı (\%42.5’ten \%44.1'e) belirtilmiştir. Çalışmanın sonucunda glutensiz diyetlerin gastrointestinal semptomları ve otizm spektrum bozukluğu davranışlarını kontrol etmede etkili olabileceği belirtilmiştir (27). Otizm spektrum bozukluklarınin tedavisinde glutensiz ve kazeinsiz diyet etkinliğinin değerlendirildiği sistematik bir derlemede, glutensiz ve kazeinsiz diyet ile ilişkili olumsuz sonuçların görülmediği ancak glutensiz ve kazeinsiz diyetin otizm spektrum bozuklukları semptomları için faydalı olduğuna dair yeterli kanıt olmadığı belirtilmiştir (28).

\section{Romatoid artrit}

Bağırsak türevli bir antijen olan gluten, romatoid artrit için de immünolojik bir tetikleyicidir (29). Romatoid artritli hastalarda, normal veya artmış düşük yoğunluklu lipoprotein (Low density lipoprotein, LDL), azalmış yüksek yoğunluklu lipoprotein (High density lipoprotein, HDL) ve yüksek trigliserit ile karakterize bir dislipidemi görülmektedir. Bu nedenle ateroskleroz ve diğer kardiyovasküler hastalık riski bu hastalarda daha yüksektir (30). Yapılan bir çalışmada; romatoid artritli hastalarda glutensiz vegan bir diyet uygulanmasının azalmış LDL ve okside LDL seviyeleri, artmış immünoglobulin A (IgA), immünoglobulin M (IgM) seviyeleri ile potansiyel olarak ateroprotektif ve anti-inflamatuar değişiklikler sağlayabileceği belirtilmiştir (31).

\section{Şizofreni}

Şizofreni hastalarının genel popülasyondan daha yüksek düzeyde antigliadin otoantikorları olduğu ve bu antikorlar ile psikiyatrik hastalıklar arasında bir bağlantı olduğu hipotezi öne sürülmüştür. Şizofreni hastalarının diyetlerinden gluten çıkarıldığında, hastaların şizofreni belirtilerinde azalma olduğu bildirilmiştir (26). Bununla birlikte şizofreni hastalarında glutensiz diyetin etkinliğini değerlendiren derleme yazılar negatif veya net olmayan sonuçlar ortaya koymaktadır $(32,33)$. Son zamanlarda glutensiz diyetin şizofreni semptomları üzerindeki olası etkisini araştıran çalışmalar arasında tutarlı bir sonuç olmadığı gösterilmiştir (26,32-34).

\section{Fibromiyalji ve endometriozis}

Fibromiyalji, geniş spektrum ile karakterize kronik kas-iskelet ağrısı sendromudur. Fibromiyaljisi olan hastalar, gluten ile ilişkili bozuklukları olan hastaların yaşadıklarına benzer semptomlara sahiptir. Fibromiyaljili 75 hastada, 24 hafta boyunca glutensiz diyet veya hipokalorik ( $\leq 1500 \mathrm{kkal} /$ gün) diyet uygulandığı randomize çalışma, gluten duyarlılığı ve fibromiyalji semptomlarında iyileşmelerle sonuçlanmıştır. Ancak, semptomlarda gözlenen değişiklikler için her iki diyet arasında fark olmadığı belirtilmiştir (35). Kronik pelvik ağrı endometriozis hastalarının \%3.8-37'sini etkilemektedir. Glutensiz diyet ve pelvik ağrı arasındaki ilişkiyi değerlendiren retrospektif bir çalışmada, glutensiz diyetin endometriozisin pelvik ağrı gibi klinik semptomlarını iyileştirebileceği sonucuna varılmıştır (36).

\section{Sporcularda Glutensiz Diyet}

Bazı sporcular performans ve dayanıklılığı arttırmak için glutensiz diyet uygulamaktadır. Çölyak hastası olmayan 910 sporcunun katıldığı bir çalışmada, \%41'inin glutensiz diyet uyguladığı saptanmıştır. Glutensiz diyet uygulayanlarm sadece \%13’ünün tıbbi nedenlerden dolayı uyguladığı belirtilmiştir. Özellikle dayanıklılık sporcularının gastrointestinal sorunların ve yorgunluğun gluten alımı ile ilişkili olduğuna inandıkları bildirilmiştir. Glutensiz diyet uygulaması için önde gelen bilgi ve rehberlik kaynaklarının; çevrimiçi kaynaklar (\%28.7), eğitmenler veya koçlar (\%26.2) ve diğer sporcuların (\%17.4) olduğu belirtilmiştir (37). Glutensiz diyetin sporcular üzerindeki etkisini araştırmak amacıyla yapılan 13 dayanıklılık bisikletçisinin dahil edildiği bir çalışmada, kısa süreli (7 gün) glutensiz diyetin 
performans, gastrointestinal semptomlar, iyilik hali, bağırsak hasarı veya inflamatuar belirteçler üzerinde anlamlı bir etkisi olmadığı bildirilmiştir (38).

\section{Glutensiz Diyetlerin Maliyeti}

Tüketicilerin glutensiz ürünlere olan taleplerinin giderek artmasına paralel olarak glutensiz ürün pazarı her geçen gün büyümektedir. Dünya çapında glutensiz ürünlerin piyasası yaklaşık olarak 15 milyar dolara ulaşmıştır (3). Glutenli ve glutensiz ürünlerin karşılaştırıldığı bir çalışmada glutensiz her ürünün, buğday bazlı muadillerinden daha pahalı olduğu gösterilmiştir. Glutensiz ürünlerin pahalılık oranının yaklaşık \%240 olduğu belirtilmiştir. En yüksek maliyet farkının ise glutenli ve glutensiz makarna arasında olduğu belirtilmiştir (39). Yapılan başka bir çalışmada, glutensiz besinlerin, gluten içeren besinlere kıyasla yaklaşık 3 katı kadar daha pahalı olduğu bildirilmiştir (7). Ancak buna rağmen 18-20 yaş arasındaki genç yetişkinlerin \%37'si ve 21-34 yaş arasındaki yetişkinlerin ise \%31'i glutensiz ürünlerin daha pahalı olmasına rağmen satın almaya istekli oldukları belirlenmiştir (31).

\section{SONUÇ VE ÖNERILLER}

Glutensiz diyetler; buğday, arpa, çavdar ve bunları içeren tüm besinlerin eliminasyonuna dayanan diyetlerdir. İşleme sırasında çapraz kontaminasyon ile ilgili endişelerden dolayı yulaf tüketimine de dikkat edilmelidir. Sağlık sorunları nedeniyle glutensiz diyet uygulaması gereken bireylere diyet örüntüsünü iyileştirmek adına doğal olarak gluten içermeyen karabuğday, kinoa, amarant gibi alternatif tahılların tüketimi önerilmelidir. Besin ögesi eksikliklerini önlemek için sebze, meyve ve kurubaklagil tüketimine önem verilmelidir.

Glutensiz diyetler vücut ağırlık kaybı sağlamanın aksine enerji, yağ, karbonhidrat ve posa gibi besin ögelerinin dengesiz alımına bağlı olarak vücut ağırlık kazanımıyla sonuçlanabilmektedir. Glutensiz besinlerin enerji ve yağ içeriği yüksek, posa içeriği düşük olduğundan, kardiyovasküler hastalıklar için potansiyel risk faktörü olabileceği düşünülmektedir. İrritabl bağırsak sendromu, şizofreni, atopi, fibromiyalji, endometriozis, atletik performans üzerine olumlu etkileri olabileceği düşünülse de glutensiz diyetlerin bu hastalıkların tedavisinde kullanılması gerektiği kesin olarak kanıtlanamamıştır. Glutenin sağlık etkilerini ve gluten içeren tahıllardan kaçınmanın olası sonuçlarını açıklığa kavuşturmak için daha fazla sayıda araştırmaya ihtiyaç vardır.

Çıkar çatışması - Conflict of interest: Yazarlar çıkar çatışması olmadığını beyan ederler. - The authors declare that they have no conflict of interest.

\section{KAYNAKLAR}

1. Aziz I, Branchi F, Sanders DS. The rise and fall of gluten! Proc Nutr Soc. 2015;74(3):221-26.

2. Köksal G, Gökmen H, Çocuk Hastalıklarında Beslenme Tedavisi. 3. Baskı. Ankara: Hatiboğlu Yayınları; 2013.

3. Amil Dias J. Celiac Disease: What do we know in 2017? GE Port J Gastroenterol. 2017;24(6):275-78.

4. Peter HR, Green MD, Christophe MD. Celiac disease. N Engl J Med. 2007;357:1731-43.

5. Zimmer KP. Nutrition and celiac disease. Curr Probl Pediatr Adolesc Health Care. 2011;41(9):244-47.

6. García-Manzanares A, Lucendo AJ. Nutritional and dietary aspects of celiac disease. Nutr Clin Pract. 2011;26(2):163-73.

7. Newberry C, McKnight L, Sarav M, Pickett-Blakely O. Going gluten free: the history and nutritional implications of today's most popular diet. Curr Gastroenterol Rep. 2017;19:54-62.

8. Catassi C, Alaedini A, Bojarski C, Bonaz B, Bouma G, Carroccio A, et al. The overlapping area of nonceliac gluten sensitivity (NCGS) and wheat-sensitive irritable bowel syndrome (IBS): An update. Nutrients. 2017;9(11):1268-84.

9. Reilly NR. The gluten-free diet: recognizing fact, fiction, and fad. J Pediatr. 2016;175:206-10.

10. Subhan FB, Chan CB. Review of dietary practices of the 21st century: facts and fallacies. Can J Diabetes. 2016;40:348-54.

11. Kautto E, Rydén P, Ivarsson A, Olsson C, Norström F, Högberg L, et al. What happens to food choices when a gluten-free diet is required? A prospective longitudinal population-based study among Swedish adolescent with coeliac disease and their peers. J Nutr Sci. 2014;3:1-10.

12. Balamtekin N, Aksoy C, Baysoy G, Uslu N, Demir H, 
Koksal G, et al. Is compliance with gluten-free diet sufficient? Diet composition of celiac patients. Turkish J Pediatr. 2015;57(4):349-74.

13. Martin J, Geisel T, Maresch C, Krieger K, Stein J. Inadequate nutrient intake in patients with celiac disease: results from a German dietary survey. Digestion 2013;87(4):240-46.

14. Saturni L, Ferretti G, Bacchetti T. The gluten-free diet: safety and nutritional quality. Nutrients. 2010;2(1):1634.

15. García-Manzanares A, Lucendo AJ. Nutritional and dietary aspects of celiac disease. Nutr Clin Pract. 2011;26(2):163-173.

16. Penagini F, Dilillo D, Meneghin F, Mameli C, Fabiano V,Zuccotti GV. Gluten-free diet in children: an approach to a nutritionally adequate and balanced diet. Nutrients. 2013;5:4553-65.

17. Theethira TG, Dennis M, Leffler DA. Nutritional consequences of celiac disease and the gluten-free diet. Expert Rev Gastroenterol Hepatol. 2014;8(2):123-29.

18. Kupper C. Dietary guidelines and implementation for celiac disease. Gastroenterology. 2005;4(1):121-27.

19. Ontiveros N, Rodríguez-Bellegarrigue CI, GaliciaRodríguez G, Vergara-Jiménez MJ, Zepeda-Gómez EM, Arámburo-Galvez JG, et al. Prevalence of self-reported gluten-related disorders and adherence to a gluten-free diet in Salvadoran adult population. Int J Environ Res Public Health. 2018;15(4):786-97.

20. Lerner A, Jeremias P, Matthias T. Gut-thyroid axis and celiac disease. Endocr Connect. 2017;6(4):52-8.

21. Sapone A, Bai JC, Ciacci C, Dolinsek J, Green PH, Hadjivassiliou M, et al. Spectrum of gluten-related disorders: consensus on new nomenclature and classification. BMC Med.2012;10:13-25.

22. Mulder CJ, van Wanrooji RL, Bakker SF, Wierdsma N, Bouma G. Gluten-free diet in gluten-related disorders. Dig Dis. 2013;31(1):57-62.

23. Molina-Infante J, Serra J, Fernandez-Bañares F, Mearin F. The low-FODMAP diet for irritable bowel syndrome: Lights and shadows. Gastroenterol Hepatol. 2016;39(2):55-65.

24. Zannini E, Arendt EK. Low FODMAPs and gluten-free foods for irritable bowel syndrome treatment: Lights and shadows. Food Res Int. 2017.

25. Vazquez-Roque MI, Camilleri M, Smyrk T, Murray JA, Marietta E, O'Neill J, et al. A controlled trial of glutenfree diet in patients with irritable bowel syndromediarrhea: effects on bowel frequency and intestinal function. Gastroenterology. 2013;144(5):903-11.

26. Niland B, Cash BD. Health benefits and adverse effects of a gluten-free diet in non-celiac disease patients.
Gastroenterol Hepatol. 2018;14(2):82-91.

27. Ghalichi F, Ghaemmaghami J, Malek A, Ostadrahimi A. Effect of gluten free diet on gastrointestinal and behavioral indices for children with autism spectrum disorders: a randomized clinical trial. World J Pediatr. 2016;12(4):436-42.

28. Piwowarczyk A, Horvath A, Lukasik J, Pisula E, Szajewska H. Gluten- and casein-free diet and autism spectrum disorders in children: a systematic review. Eur J Nutr. 2018;57(2):433-40.

29. Badsha $H$. Role of diet in influencing rheumatoid arthritis disease activity. Open Rheumatol J. 2018;12:1928.

30. El-Chammas K, Danner E. Gluten-free diet in nonceliac disease. Nutr Clin Pract. 2011;26(3):294-99.

31. Elkan AC, Sjöberg B, Kolsrud B, Ringertz B, Hafström I, Frostegård J. Gluten-free vegan diet induces decreased LDL and oxidized LDL levels and raised atheroprotective natural antibodies against phosphorylcholine in patients with rheumatoid arthritis: a randomized study. Arthritis Res Ther. 2008;10(2):34-42.

32. Ergün C, Urhan M, Ayer A. A review on the relationship between gluten and schizophrenia: Is gluten the cause? Nutr Neurosci. 2018;21(7):455-66.

33. Brietzke E, Cerqueira RO, Mansur RB, Mclntyre RS. Gluten related illnesses and severe mental disorders: a comprehensive review. Neurosci Biobehav Rev. 2018;84:368-75.

34. Levinta A, Mukovozov I, Tsoutsoulas C. Use of glutenfree diet in schizophrenia. A systematic review. Adv Nutr. 2018;9(6):824-32.

35. Slim M, Molina-Barea R, Garcia-Leiva JM, RodríguezLopez CM, Morillas-Argues P, Rico-Villademoros F, et al. The effects of gluten-free diet versus hypocaloric diet among patients with fibromyalgia experiencing gluten sensitivity symptoms: protocol for a pilot, openlabel, randomized clinical trial. Contemp Clin Trials. 2015;40:193-98.

36. Marziali M, Capozzolo T. Role of gluten-free diet in the management of chronic pelvic pain of deep infiltranting endometriosis. J Minim Invasice Gynecol. 2015;22(6):512.

37. Lis DM, Stellingwerff T, Shing CM, Ahuja KD, Fell JW. Exploring the popularity, experiences, and beliefs surrounding gluten-free diets in nonceliac athletes. Int J Sport Nutr Exerc Metab. 2015;25(1):37-45.

38. Lis D, Stellingwerff T, Kitic CM, Ahuja KD, Fell J. No effects of a short-term gluten-free diet on performance in nonceliac athletes. Med Sci Sports Exerc. 2015;47(12):2563-70.

39. Lee AR, Ng DL, Zivin J, Green PH. Economic burden of a gluten-free diet. J Hum Nutr Diet. 2007;20:423-30. 